811.163'366.54

811 '366.54(497)

https://doi.org/10.18485/sj.2018.23.1.31

НАИЉЕ Р. МАЉА ИМАМИ*

Универзитет у Београду

Филолошки факултет
Оригинални научни рад

Примљен: 01. 04. 2018.

Прихваћен: 29. 01. 2018.

\title{
СИНКРЕТИЗАМ ГЕНИТИВА И ДАТИВА У БАЛКАНСКОМ АРЕАЛУ
}

У овом раду се бавимо синкретизмом генитива и датива, феноменом присутним у албанском, румунском и грчком језику. Циљ нам је да утврдимо како је дошло до морфосинтаксичког изједначења генитива и датива, што је карактеристика већине балканских језика. Међу главним хипотезама које су до данас постављане у вези с овим питањем јесу оне које настанак те појаве објашњавају: (а) утицајем старог балканског супстрата, (б) утицајем грчког или латинског језика и (в) независним развојем у појединим балканским језицима. Углавном ћемо се фокусирати на албански, грчки, румунски и бугарски језик. Своје излагање ћемо поткрепити различитим примерима из ових језика. Анализом једног одређеног броја примера, дошли смо до закључка да хомонимија између ова два падежа није увек стабилна и да порекло овог феномена до данас није у потпуности разјашњено. Такође смо закључили да свођење генитива и датива на један облик показује три тенденције: (а) апсорпцију генитива у датив (румунски и албански), (б) потискивање дативских облика наставцима за генитив (грчки) и (в) употреба номинатива са предлогом на да би се исказало значење генитива и датива (бугарски).

Кључне речи: синкретизам, генитив/датив, балкански ареал 


\section{УВОД}

Баерман синкретизам дефинише као комбиновање више различитих посебних функција у један облик, што Јакобсон назива „неутрализација падежа" (Јакобсон 1936/1984: 59-103), што подразумева уочљиву асиметрију између парадигми у оквиру једног језика, што води до полисемије падежа где један исти облик изражава две или понекад и више функција падежа. Идеја да два или више различитих морфолошких падежа могу да буду подвргнути синкретизму, што представља широку карактеристику у дијахроном развоју великог броја језика, генерално потиче од претпоставке да мора да постоји некакав основни афинитет (или семантички или морфосинтаксички) између функција које могу да се изразе на исти начин” (Баерман 2005; Катасо 2011: 71).

Хрватски лингвиста Шрепел је 1890. дефинисао да синкретизам падежа настаје кад два падежна облика замене своје функције, па се затим неко време упоредо употребљавају оба облика за исту функцију, док најзад један облик не надвлада. „Узроци синкретизма су разни: синкретизам може настати, ако се падежи у спољашњем облику изједначе, нпр., у латинском ген. и локатив, у грчком је само један примјер: датив и локатив; а још је обичније, да се функције двају падежа изједначе, нпр., у грчком датив и инструментал, кад инструментал значи лице, које врши радњу. Тако је у славенским језицима генитив синкретистичан, срастао од генитива и аблатива, као и грчки генитив" (Шрепел 1890: 3).

Чабеј напомиње да се у индоевропским језицима у коме су ишчезли неки падежи, то догодило у врло раном периоду. Такође, велики број именица мушког рода у вокативу и у номинативу имају исти облик. Та појава, изједначење падежа, када се један падеж стапа, односно преузима облик другог падежа, назива се синкретизам. Занимљиво је, да је тај термин настао по називу грчког острва Крит, односно по облику његовог назива Крета, у споју с грчким префиксом бov 'заједно, скупа': син+Крета+изам, јер су се на том острву „стопили” различити народи који су на њему живели (Чабеј 1986: 96).

Међу главним хипотезама које су се до данас постављале у вези с овим питањем, биле су оне које виде настанак те појаве под утицајем старог балканског супстрата, или под утицајем грчког или латинског језика, или као појава која, барем, у неколико балканских језика, треба да се размотри као унутрашњи независни развој.

Главни представник хипотезе о утицају супстрата био је Франц Миклошић. Међу наслеђеним појавама од супстрата, убраја и означавање генитив/датива преко истог облика у бугарском, румунском, грчком и албанском језику. Он је веровао да је тај елемент из прошлости близак с данашњим албанским 
језиком. Ова хипотеза нити може са сигурношћу да се одбаци, нити да се прихвати. Демирај напомиње да се не може с једном непознаницом решити једна друга непознаница. Ми не знамо да ли је илирски, трачки, протобугарски или неки други супстрат имао изједначење падежних облика генитива и датива. Протобугарски супстрат у том случају може да се изузме, ако се узме у обзир да у бугарском језику та појава не може бити ранија него што је у другим балканским језицима (Демирај 2004: 75-76).

Што се тиче хипотезе, према којој настанак ове појаве у балканским језицима треба тражити у грчком језику, њу је индиректно први изнео Сандфелд. Након што је образложио да се присуство заједничког падежног облика за генитив/датив у грчком потврђује већ у І. веку наше ере, ставља у први план сличну појаву и у другим балканским језицима и мало више се задржава на конструкцијама у бугарском, признајући да се у старом бугарском налазе многи примери употребе датива уместо генитива. Везано за ово констатује: „Ово не смета да се претпостави једна веза између ових језика на тој тачки” (Сандфелд 1930: 185).

Међутим, ако имамо у виду општи став Сандфелда о великом утицају грчког на друге балканске језике, онда се може потвдити да је према његовом мишљењу, једна од две струје, које су утицале на ширење појаве у балканским језицима, била грчка струја. Али у том случају он је грчки утицај изгледа претпоставио само за бугарски и албански. Претпоставка о утицају грчког на изједначењу облика генитива и датива у балканским језицима није наишла на подршку. Међутим не треба свакако одбацити тврдње за бугарски и македонски.

Када је реч о албанском језику, Демирај сматра да се грчки утицај тешко може аргументовати, али треба да се има у виду да је ова појава у албанском језику релативно веома стара, можда и старија него у грчком. Неколико других лингвиста порекло ове појаве у балканским језицима, или у некима од њих, тражили су у вулгарном латинском. Сандфелд је прихватио хипотезу да је у ширењу ове појаве у балканским језицима, осим грчког, имао утицаја и латински језик (Демирај 2004: 77).

Хипотеза о латинском утицају на ову појаву и на њено ширење у балканским језицима, заснивала се:

a) На раније документованим појавама,

б) На утицају који је овај језик имао на балканске језике током вишевековног римског владања на Балкану. Тврдња да је латински језик утицао на флексије у албанском језику, „равна је нули” (Педерсен 2003: 125). 
С обзиром на то да се ова појава релативно касно јавила у бугарском језику, такође се искључује директан утицај латинског језика. Када је реч о румунском језику, у том случају може се говорити да је флексију наследио из латинског језика. Демирај истиче чињеницу да се та појава јавља у свим балканским језицима, у којима постоје и друге заједничке граматичке карактеристике, мада је она присутна и у ванбалканским језицима. Међутим, овде одлучујуће је заједничка појава у балканском језичком савезу, која је током свог историјског језичког развоја у балканским језицима развила неколико заједничких особина, међу којима и формално изједначење генитива и датива. Када је у питању настанак ове појаве у разним балканским језицима, изгледа да одговор за то треба тражити у паралелном развоју тих језика. Другим речима, ранија појава у грчком, албанском и румунском језику била је независан развој у сваком од тих језика. Та паралелна еволуција условљена је ранијом тенденцијом та три језика ка упрошћавању деклинација именица и заменица. Такође, и у бугарском и македонском језику може се претпоставити независан развој те појаве, иако не треба одбацити могућност утицаја од стране суседних језика, румунског и грчког (Демирај 2004: 77-78).

Такође, за настанак овог феномена, Катасо наводи три хипотезе о пореклу синкретизма генитива и датива: (1) хипотеза да је романског порекла и да се сукцесивно ширила на балканском ареалу преко румунског, јер је исти облик за генитив и датив потврђен за именице женског рода у једнини 1. деклинације у класичном латинском (rosa 'ружа' - ген/дат rosae). О томе сведоче и бројни натписи нађени у вулгарном латинском у Далмацији и у подунавском региону (нпр., filius regi vs. filius regis); (2) хипотеза да је ова појава можда настала у бугарском и македонском, језицима без падежа, у којима се значења ген/дат изражавају помоћу тзв. на фразе; (3) хипотеза да се порекло спајања датива и генитива може наћи у грчком „негде у првим вековима наше ере”, како истиче Сандфелд (1930: 186), као средство за поједностављење система флексијских облика.

\section{Синкретизам генитива и датива у балканском ареалу}

Многи лингвисти посебну пажњу су посветили управо синкретизму падежа у балканском језичком ареалу. Балканско једначење генитива и датива доказује да се у процесу билингвизма појачавају опште тенденције у унутрашњем, самосталном развоју појединачних језика у балканском ареалу. Асенова истиче да су узајамни утицаји језика много сложенији процеси од директног утицаја или непосредног преузимања туђих елемената и модела. Као непосредна последица унификације генитива и датива јавља се друга важна особина балканских језика - употреба облика датива (у грчком генитива) личних и повратних заменица у служби присвојних заменица (Асенова 2002: 84). 
Синкретизам у суштини показује три тенденције: док се за румунски и албански датив може рећи да је апсорбовао генитив, наслеђени наставак за датив користи се за изражавање генитива. Супротно важи за грчки, где се генитив користи да исказује датив (као генитив одвајања) (Банфи 1985:52). У бугарском, уместо тога, генитив/датив се изражава кроз тзв. на фразе, односно уз употребу предлога на (Катасо 2011:73).

Код синкретизма генитива и датива у бугарском и румунском формални тумач функција оба падежа постао је датив:

рум. Lumina stinsului amor /Ne urmăreşte încă. (M. Eminescu) /Светлост угасле љубави још увек нас прати/, Dă orizon nemărginit/Singurătății mării. (M. Eminescu)/Пружа се бескрајни хоризонт морске пустоши/.

У бугарској синтакси ово спајање уочава се код изражавања старих дативских и генитивних односа са једним истим предлогом - на: Лудориите на сина му го бяха накарали да си развали навищите. /Лудости његовог сина натерале су га да промени своје навике (Ј. Јовков); Знайт ли кой е тоя-заговори гордо и тьржествено Киро на другарите си. (Ј. Јовков) /Знате ли ко је овај - поче Киро да говори поносно и свечано својим друговима.

У грчком, напротив, генитив је прихватио и функције датива: Ta $\beta \imath \beta \lambda i \alpha$

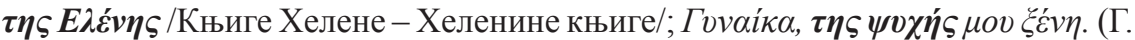
$\Sigma \varepsilon \varphi \varepsilon ́ p \eta \varsigma)$ /Жена - страна мојој души./ И у албанском се облици овог падежа не разликују: Dhimovica bënte ç'bënte dhe i thoshte Kolit. (Th. Kacori) /Димова чини шта чини и каже Колију;...kishte dhënё shpirt me emrin e Minait nё gojë. (Th. Kacori) /Издахнула је са Минаитим именом на устима (Асенова 2002:81).

Према Катасу, постоји потпуна истоветност између изражавања датива и генитива у номиналним изразима. $\mathrm{U}$ румунском ajutor populatei има два значења, једно у коме populatiei датив - ajutor захтева дативски објекат, а објекат у генитиву и ближе одређује именицу).

Табела 1. Анализа синтаксичког понамања генитива и датива

\begin{tabular}{|c|c|c|}
\hline & Генитив & Датив \\
\hline Румунски & casa bătrânul-ui & are spus acesta bătrânul-ui \\
\hline Албански & shtëpia e plak-ut & ia tha plak-ut \\
\hline Бугарски & $\begin{array}{l}\text { kăštata na starikăt } \\
\text { 'кућа старца - старчева кућа' }\end{array}$ & $\begin{array}{l}\text { (mu) reče na starikăt } \\
\text { 'рече старцу' }\end{array}$ \\
\hline Грчки & $\begin{array}{l}\text { to spiti tou anthrop-ou } \\
\text { 'кућа човека - човекова кућа' }\end{array}$ & $\begin{array}{l}\text { to spiti tou anthropou/ston anthropo } \\
\text { 'кућа човека / човеку' }\end{array}$ \\
\hline
\end{tabular}


Анализа синтаксичког понашања генитива и датива у случају појединачног језика показује да ова кореспонденција није потпуна (Катасо 2011: 74).

Асенова напомиње да се као непосредна последица унификације генитив/датива јавља употреба кратких облика датива (у грчком језику генитива) личних и повратних заменица у служби присвојних заменица. Већ у класичном старогрчком један од начина за изражавање припадности била је лична

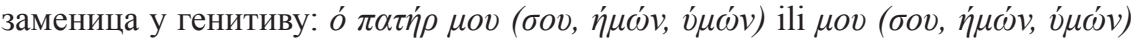

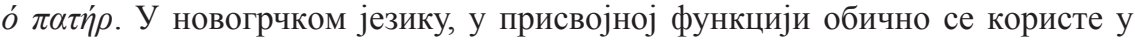
једнини облици генитива, а у множини, облици акузатива личних заменица:

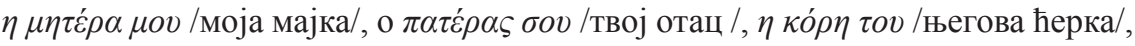

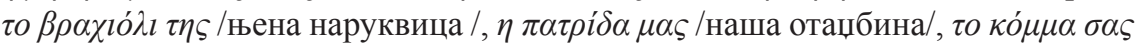
/ваша партија/, итд. У историји грчког језика датив се замењује како генитивом,

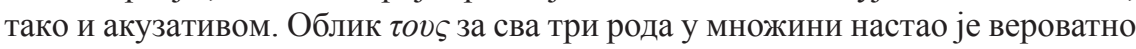
од генитива једнине $\tau o v$ и наставком -ৎ за множину (Асенова 2002: 84).

Формални синкретизам генитив/датива јавља се као општа појава и у свим говорима албанског језика, укључујући овде и оне у Грчкој и Арбреше у Италији. Историјски гледано, како наводи Демирај, у албанском језику наставци у једнини повезују се са старим наставком за датив, у множини наставак -e (данас -ve), са старим наставком за генитив. Дакле, у албанском језику у једнини је ишчезао стари облик генитива, док у множини облик генитива је утицао да нестане стари облик датива (Демирај 2004: 70; 1986: 275). Спајање генитива и датива у албанском језику извршено је много пре почетка писменог периода. Наставак за генитив једнине у раној фази индоевропских језика био је -s (у неким случајевима $-e s,-o s)$, док је наставак за датив био дифтонг, који је временом прерастао у један дуги вокал ${ }^{1}$. По свему судећи, ширење наставка датива једнине у генитив потврђено је у оно време када је генитив изгубио свој наставак. Према томе, ширење очуваног наставка датива и у генитив омогућено је и због потребе да се формално разликују ова два падежа од номинатива и акузатива у неодређеном виду, који су такође остали без падежних наставака (Демирај 1986: 257).

За разлику од Демираја, Сељман Риза истиче да је датив у једнини „коинцидирао фонетски" са одговарајућим генитивом", што је утицало у каснијем развоју албанског језика на морфемско спајање датива једнине с генитивом (без члана), а затим је и генитив множине (без члана) почео да се користи као датив; све је то утицало да и наставак -sh датив/аблатива у множини почне да се употребљава само за аблатив (Риза 1965: 28).

\footnotetext{
${ }^{1}$ Наставци -и и -е као дифтонзи дуго време су били дуги вокали а позната је чињеница да су се дуги вокали сачували много боље у односу на кратке вокале и у позицији ван акцента (Демирај 1986: 276).
} 
Иначе, тенденција ка стапању генитива и датива у један падеж отворено је питање у албанској граматици. Функција генитива је јасна: то је падеж припадности. Лице или предмет чији је власник одређен, индивидуализован, има функцију одређивања именице. По облику, генитив се разликује од датива само по препозитивном члану, који је, по мишљењу Фатмира Агалиуа, једно спољно аналитичко средство. По њему, правилније би било да се говори о дативу који испуњава и функције генитива када добије препозитивни члан, дакле, о дативу с поимениченим обликом који функционише као генитив. Отприлике као у румунском језику, с том разликом што се препозитљивни члан појављује само када одредбена именица нема препозитивни члан или када између њега и именице у генитив/дативу улази нека друга реч (Агалиу 1980: 163).

Катасо констатује да се генитив и датив, осим по својим морфолошким наставцима, не подударају савршено у албанском језику:

a) Ia dhashë librin Marisë. /Дао сам књигу Марији./Датив

b) Libri është i Marisë. /Књига је Маријина./ Генитив

Асенова наводи да је унификација датива и генитива генерализована појава у општерумунском, која налази место још у вулгарном латинском, тако да његова појава у румунском од 16. века не поставља проблеме. „Доминација датива над генитивом манифестује се и у употреби предлога $a$, $a d$ у дакорумунском и арумунском приликом исказивања генитивних односа, на пример: дакорум. a lupului /vuku/, a nopților /ноћима/; арум. a lupluĭ, nopților. $\mathrm{C}$ друге стране, док је предлог de специјализован у осталим романским језицима за изражавање генитива, у румунском језику његове конструкције нису еквивалентне генитиву, осим ако изражавају посесивност: друм. Din mijloc de casă /од средине куће/, la margine de codru /на ободима шуме/; арум. uşa di călivă /врата колибе/ (Асенова 2002: 82-83).

У историји грчког и бугарског језика, по бугарском лингвисту Мирчеву (1966: 289), како наводи Асенова, међу најранија сведочанства синкретизма датива и генитива убрајају се случајеви везани за личне заменице, а већ у старобугарском периоду облици датива личних заменица означавали су припадност. Двострука употреба личне заменице у генитиву (посесивне и атрибутивне) у грчком и старобугарском двоструко замењујући датив типа отврзи очи рабоу твоему, где облик датива у служби индиректног објекта има истовремено и посесивно значење, доприноси синкретизму генитива и датива.

У албанском језику, како наводи Демирај, постоји могућност да је изједначење генитива и датива добијено у исто време у оба броја. Дакле, процес изједначења падежа генитива и датива је последица два фактора: 
(a) фонетски фактор (редукција и губитак падежног наставка који је био мање чуван/заштићен), и

(б) аналошки фактор (простирање наставка једног падежа и на други).

Током своје историјске еволуције албански језик је сачувао формалну разлику генитива и датива, за разлику од друга два најфреквентнија падежа - номинатива и акузатива. С друге стране, имајући у виду да генитив и датив имају своје поље употребе у реченици, након изједначења ова два падежа, раније или касније, у употреби осећала се потреба да треба да се разликују са формалне стране. Та појава наилази на подршку, макар и посредно, у чињеници да се и у језицима који су изгубили систем деклинације, функције и карактеристике ова два падежа формално се разликују помоћу посебних предлога, који се јављају испред именица, који се користе у функцији одредбе, заправо у функцији неправог објекта, као што се на пример десило са романским језицима на западу, у енглеском, итд.

Формалну разлику генитива од датива чини препозитивни члан генитива, који је његов саставни део, и подудара се у роду, броју и падежу са именицом коју одређује. На пример: mali i Dajtit / планина Дајт/, fusha e Dajtit /поље Дајт/, malit të Dajtit, fushës së Dajtit. Ово усклађивање „препозитивног члана” генитива са именицом, што се историјски може објаснити, када се има у виду да је овај „препозитивни члан” добијен од механичког понављања препозитивног члана именице којој претходи. Али синтаксичко усклађивање „предњег члана" генитива са именицом којој претходи и после његовог кристалисања као саставни део овог падежа, временом је нестало као непотребно. У чувању овог синтаксичког усклађивања „препозитивног члана” генитива утицало је можда и чување истог типа усклађивања „препозитивног члана” код придева са чланом, који се усклађују са именицом у роду, падежу и броју, и углавном се исказују помоћу разних облика њиховог „препозитивног члана” (Демирај 1986: 258).

Подударање падежа генитива и датива у румунском језику, има неколико сличних карактеристика као и у албанском. Међутим постоји једна значајна разлика између ова два језика. У румунском језику именице мушког и средњег рода ${ }^{2}$ у неодређеном виду, у једнини и множини, имају заједнички облик у свим падежима, тако да се генитив и датив код ових именица разликују само уз помоћ детерминатора који се ставља испред, углавном, према падежним облицима неодређеног члана.

${ }^{2}$ У румунским граматикама именице средњег рода које означавају ствари, а које у једнини се јављају као именице мушког рода док у множини као именице женског рода, као нпр. deal $\sim$ deal-uri "kodër kodr-a"/брдо-брда/, studiu studii "studim studim-e"/студија-студије/, и др. (Демирај 2004: 73). 


\begin{tabular}{|c|c|c|c|c|}
\hline \multicolumn{2}{|c|}{ Једнина } & \multicolumn{3}{c|}{ Множина } \\
\hline \multicolumn{2}{|c|}{ Именица мушког рода } & \multicolumn{2}{|c|}{ Именица средњег рода } & \\
\hline Акузатив & (un) om & deal & (nipte) oameni & dealuri \\
\hline Генитив & ( (а unui) om & deal & (a unor) oameni & dealuri \\
\hline Датив & (unui) om & deal & (unor) oameni & dealuri \\
\hline
\end{tabular}

И именице женског рода у деклинацији неодређеног вида разликују облик генитива и датива, од оног у номинативу и акузативу само у једнини. (Демирај 2004: 73).

\begin{tabular}{|c|c|c|}
\hline & Једнина & Множина \\
\hline Акузатив & (o) cas£ & nipte case \\
\hline Генитив & (a unei) cas-e & (a unor) case \\
\hline Датив & (unei) cas-e & (unor) case \\
\hline
\end{tabular}

Генитив у румунском језику се разликује од датива по препозитивном члану al (a, ai, ale). За разлику од албанског језика, додавање препозитивног члана генитива у румунском дешава се само када се јавља после именице у неодређеном виду. На пример: рум. o casă a vecinului; алб. пjё shtëpi e fqinjit /кућа једног суседа/; рум. casa vecinului; алб. shtëpia e fqinjit/суседова кућа/. Претпоставља се да препозитивни члан генитива у румунском није много стар, и да је настао између 12-14. века. Може се тврдити да је појава препозитивног члана у генитиву у румунском језику настала после изједначавања овог падежа с дативом, као последица а не узрок. Формално изједначавање генитива и датива почело је већ у периоду дунавског латинског (Ibidem).

Што се тиче бугарског и македонског, претпоставља се да је синтетички тип деклинација ишчезао у 12-14. веку. Овде није реч о изједначењу синтетичких падежних облика генитива и датива, већ о простирању устаљеног облика номинатива када му претходе предлози „на” у функцији генитива и датива. На пример, на бугарском: книгата на ученикот „libri i nxënёsit” /ученикова књига/ и (му) рече на ученикот „I tha nхёnёsit” /рече ученику/ (ибидем).

Употреба предлога на да би се изказало значење датива у бугарском није стара. Предлог на испред именице у дативу нигде се не појављује у документима средњобугарског (12-14. века). Према томе, садашњи облик датива са предлогом на, како се чини, није се појавио пре 15. века, већ касније (Катасо 2011: 74-80). 
Табела 2. Реченични примери синкретизма генитива и датива у албанском, арумунском, румунском, бугарском, македонском и грчком језику, у односу на српски језик

\begin{tabular}{|c|c|c|}
\hline Језик & Датив & Генитив \\
\hline Српски & Дао сам књигу Марији. & $\begin{array}{l}\text { То је књига Марије Пет- } \\
\text { ровић. }\end{array}$ \\
\hline Албански & Librin ia dhashë Marisë. & Libri është i Marisë. \\
\hline Арумунски & Vivlia lju dedu ali Marii. & Vivlia easti ali Marii. \\
\hline Румунски & $\begin{array}{l}\text { I-am dat cartea Mariei. } \\
\text { I-am dat cartea lui Marian. }\end{array}$ & $\begin{array}{l}\text { Este cartea Mariei. } \\
\text { Este cartea lui Marian. }\end{array}$ \\
\hline Бугарски & Дадох книгата на Мария & Книгата е на Мария \\
\hline Македонски & Ѝ ја дадов книгата на Марија. & Книгата е на Марија. \\
\hline Грчки & 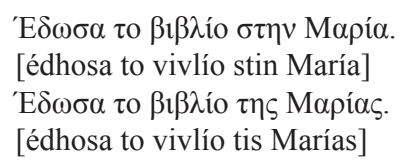 & 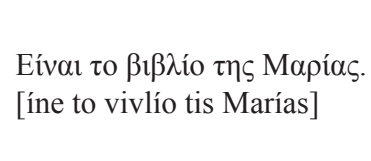 \\
\hline & 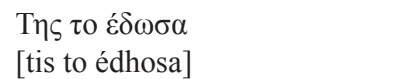 & $\begin{array}{l}\text { Eíval } \tau \text { o } \beta 1 \beta \lambda \text { ío } \tau \eta s . \\
\text { [íne to vivlío tis] }\end{array}$ \\
\hline
\end{tabular}

Преузето са интернета: http://en.wikipedia.org/wiki/Balkan_sprachbund (15.08.2012.)

Претпоставља се да разликовање генитива од датива помоћу препозитивног члана датира пре првих сачуваних текстова Ђона Бузукуа и Леке Матренге (16. век). Демирај сматра да хипотеза да је препозитивни члан додат генитиву због потребе да се овај падеж разликује од датива, језички поткрепљена. Стварање једног оваквог граматичког индикатора, као што је „препозитивни члан”, који је карактеристичан за албански језик и делимично за румунски, не би било потребно у случају да су се падежи генитив и датив у ранијем периоду поистоветили у смислу облика. „Ако се и претпостави да је додавање препозитивног члана била једна проста граматичка хиперкарактеризација (редунданција), опет остаје неразјашњено питање формалног поистовећења ова два падежа" (Демирај 1985: 256).

У том случају могло се очекивати да ће се генитив, после додавања препозитивног члана, временом редуковати и на крају изгубити свој падежни наставак. Из тог разлога, проистиче да владајуће мишљење, да је додавање 
препозитивног члана генитиву последица, а не узрок изједначења овог падежа са дативом (Ibidem).

Станишић истиче да у албанском језику постоји „облички синкретизам трију зависних падежа - генитива, датива и аблатива”, али да се са формалне стране једино датив чува. „Он је овде потпуно самосталан и, штавише,, изузетно слободан падежни облик, што међу балканским језицима има паралелу само у српскохрватском" (Станишић 1989: 360-361).

По свему судећи, процес формалног изједначавања генитива и датива у албанском језику, у даљој еволуцији десио се због фонетских промена. Као што се зна, падежни наставци, поготову након устаљења акцента обично над слогом који није завршни (Демирај 2004: 71), налазећи се у ненаглашеној позицији, изазвали су постепене редукције, које су у неколико случајева и узроковале њихово поптуно губљење. Овакву судбину су претрпели, између осталих, и наставци за номинатив и акузатив једнине за именице мушког рода и средњег рода, као и наставак за акузатив једнине именица мушког и женског рода, јер су се све оне састојале од сугласника у незаштићеној позицији на крају.

Кољец Топали недвосмислено указује на то да албански језик има само четири падежа, „који се разликују посебним наставцима (номинатив, генитив/ датив, акузатив, аблатив”. Он истиче да су ти падежи обухваћени синкретизмом. „Стога, ако узмемо ову појаву, произлази да је њихов број још мањи: два у неодређеном виду једнине (номинатив/акузатив генитив/датив/аблатив) и три у одређеном виду множине (номинатив генитив/датаив/аблатаив акузатив), три у неодређеном виду множине (номинатив/акузатив генитив/ датив аблатив), и два у одређеном виду (номинатив/акузатив $\sim$ генитив/датив/аблатив)" (Топали 2011: 121).

\section{ЗАКљУЧАК}

Развој аналитизма у албанском, грчком, бугарском и румунском језику остварен је кроз једнаке међуетапе, од којих важно место заузима синкретизам - појава која претходи аналитичком изражавању истих синтаксичких односа. Тада је почео да се формира падежни систем „новобалканског типа” (номинатив, генитив-датив, акузатив):

грчки: (1) номинатив, (2) генитив, (3) акузатив, (4) вокатив румунски: (1) номинатив/акузатив, (2) генитив/датив, (3) вокатив албански: (1) номинатив, (2) генитив, (3) датив, (4) акузатив, (5) аблатив. 
Такође, редукција генитива и датива показује три тенденције: апсорпцију генитив > датива (румунски, албански), супротан случај (грчки) и употреба номинатива са предлогом на да би се исказало значење датива и генитива (бугарски).

У новије време албански језик показује јасну тенденцију даље редукције падежа са пет на четири, пошто већ у великој мери синкретизам обједињује генитив, датив и аблатив. Може се рећи да албански језик данас има четири падежа у неодређеном виду, док у одређеном виду три падежа, јер не постоји аблатив за одређени вид, односно ишчезао је наставак за одређени вид множине -shit (maleshit), а с тим је, како истиче Агалиу, нестао и овај падеж у одређеном виду. Кољец Топали је изричит: „аблатив се данас може карактерисати као граматички облик реликтног карактера".

Албански језик показује неупоредиво више сличности са другим балканским језицима, с којима дели известан број карактеристичних подударности готово у потпуности непознати српском језику, па је стога управо у том контексту контрастивно поређење падежних система та два језика утолико значајније јер је реч о два „најсинтетичнија језика на Балкану”.

Може се рећи да данас једино бугарски и македонски језик међу балканским језицима имају потпуно развијен аналитизам у именичком систему. То је основна црта њихове граматичке структуре, која га битно супротставља синтетизму словенских језика са очуваном архаичном деклинацијом.

Остали балкански језици не могу да се назову аналитичним - у сваком од њих могу се набројати од три (у грчком) до пет (у албанском) падежа, али они нису ни синтетични, ако се има у виду њихов врло сложен деклинациони систем. (Асенова 2002: 76).

Српски језик убраја се у синтетичко-аналитичке језике, у чијем падежном систему важну морфосинтаксичну функцију имају предлози. За разлику од својих источних суседа (бугарског и македонског), српски језик добро чува категорију падежа, а такође, за разлику од неких словенских језика је очувао и вокатив.

\section{ЛИТЕРАТУРА}

Агалиу 1980: Fatmir Agalliu, Sa rasa ka gjuha shqipe, Studime filologjike, Tiranë, 114-127.

Асенова 2002: Petяa Asenova, Балканска лингвистика: Основни проблем на балканскиј језиков сајуз, В. Т'рново : Фабер.

Банфи 1985: E. Banfi, Linguistica balcanica. Bologna : Zanichelli. 
Баерман 2005: Baerman M. Typology and the formal modelling of syncretism. Yearbook of Morphology, 2004, pp. 41-72. Repository URL: http://epubs.surrey.ac.uk/1308/.

Чабеj 1986: Ećrem Čabej, Hyrje në studimin krahasues të gjuhëve indoevropiane. Studime gjuhësore, VII /Eqrem Çabej/. Prishtinë: Rilindja.

Демирај 2004: Šaban Demiraj, Gjuhësi ballkanike/Balkanska lingvistika]. Tiranë: Shkenca http://dielli.net/pdf/historia/GjuhesiBallkanike.pdf 15.06.2012.)

Демирај 1986: Šaban Demiraj, Gramatikë historike e gjuhës shqipe. Tiranë : 8 Nëntori

Јакобсон 1936/1984: Roman Jakobson 1936/1984: Jakobson, R.O. 1936/1984. Contribution to the general theory of case: general meanings of the Russian cases [translation of Beitrag zur allgemeinen Kasuslehre: Gesamtbedeutung der russischen Kasus, originally in TCLP 4]. In: L. R. Waugh and M. Halle (eds) Roman Jakobson. Russian and Slavic grammar: Studies 1931-1981. Berlin: Mouton de Gruyter. 59-103.

Катасо 2011: Cattaso N. Genitive-Dative Syncretism in the Balkan Sprachbund: An InvitationtoDiscussion. http://www.skase.sk/Volumes/JTL19/ pdf_doc/04.pdf 15.06.2012.)

Миклошић 1861: Franz Miklosich, Die slavischen Elemente im Rumunischen. Denkschriften der Kaiserlichen Akademie der Wissenschaften, Philos. - histor. Classe VII). Wien 1861.

Менесланд 2009: Svein Mennesland, Padežna neutralizacija opozicije cilja kretanja i mirovanja u crnogorskom jeziku. Njegoševi dani, Zbornik radova, Podgorica: Univerzitet Crne Gore, s. 267-274.

Мирчев 1966: Кирил Мирчев, Историческа граматика на българсия език. Скопје.

Педерсен 2003: Holger Pedersen, Studime për gjuhën shqipe. Prishtinë: Akademia e Shkencave dhe e Arteve e Kosovës.

Риза 1965: Selman Riza, Emrat në shqipe: Sistemi i rasavet dhe tipet e lakimit: Tiranë: Universiteti Shtetor i Tiranës.

Сандфелд 1930: Kristian Sandfeld, Balkanski jezici. Knjiga o Balkanu, I. Beograd: Izdanje Balkanskoga instituta, str. 260-267.

Станишић 1989: Vanja Stanišić, O nekim sličnostima u padežnom sistemu između albanskog i srpskohrvatskog jezika. Balcanica, XX. Beograd, s. $357-367$. 
Шрепел 1890: Milivoj Šrepel, Analogija u sintaksi gramatičnih padeža latinskoga $i$ hrvatskoga jezika. Rad Jugoslavenske akademije znanosti i umjetnosti. Razredi filologičko-historički i filosofičko-juridički. Zagreb, knj. 31, 1-29. http://www.archive.org/ stream/radjugoslavensk08umjegoog/radjugoslavensk08umjeg oog_djvu.txt 15.06.2012.)

Топали 2011: Kolec Topalli: Gramatika historike e gjuhës shqipe, Tiranë, Botimet albanologjike.

\title{
SYNCRETISM OF GENITIVE AND DATIVE IN THE BALKAN SPRACHBUND
}

\begin{abstract}
Summary
In this article we discuss syncretism of genitive and dative, a phenomenon present in the Albanian, Romanian, and Greek language. Our goal is to determine the occurrence of morphosyntactic alignment of genitive and dative case, which is characteristic of the majority of the languages of the Balkans. Among main hypothesis raised to the present day are those which view this phenomenon as consequence of the influence of: (a) the old Balkan substrate, (b) the Greek and Latin language, (c) as a phenomenon with an independent internal development in some of the Balkan languages. In our paper we will focus mostly on the Albanian, Greek, Romanian, and Bulgarian language. Our paper will be substantiated with different examples from these languages. Through the analysis of a certain number of examples, we conclude that the homonymy between these two cases is not always stable and that the origin of this phenomenon is not fully explained to this date. We have also concluded that reduction of genitive/dative case in one form has three tendencies: (a) absorption of genitive > dative (Romanian, Albanian), (b) suppression of dative forms through endings for genitive case (Greek language), and (c) the use of dative with the proposition -на to demonstrate genitive and dative meaning (in the Bulgarian language).
\end{abstract}

Key words: syncretism, genitive/dative, the Balkan language areal 